\title{
Pendidikan Seks Dalam Islam Berbasis Komunikasi Orangtua-Anak: Langkah Pencegahan LGBT Pada Anak
}

\author{
Dewi Eko Wati ${ }^{1}$ \\ Dosen PG PAUD Universitas Ahmad Dahlan Yogyakarta ${ }^{1}$ \\ dewi.ekowati@pgpaud.uad.ac.id
}

\begin{abstract}
The discussion of this article is restricted to LGBT review of psychological and religious side. The purpose of this article is to provide special insight to parents on the importance of a warm and harmonious relationship between parent and children as an LGBT prevention through sex education in children in Islamic religious review. The method used was literature study. From religious review, MUI banned LGBT behavior because it is a crime that can cause diseases that are harmful to health such as syphilis, hepatitis $B$, and HIV/AIDS. From psychology review, LGBT can interfere with one's psychological welfare. Therefore, prevention need to be done strart from the family. Sex education on children should be done in the relationship of parents and children who have warm and harmonious communication. Parent-child communication based on trust and openness becomes key in sex education for children.
\end{abstract}

Keywords: sex education, communication, parents-child, lgbt

\section{Abstrak}

Pembahasan artikel ini dibatasi pada LGBT ditinjau dari sisi psikologi dan agama. Tujuan penulisan artikel ini untuk memberikan wawasan khususnya kepada orangtua mengenai pentingnya hubungan yang hangat dan harmonis antara orangtua dan anak sebagai upaya pencegahan LGBT melalui penanaman pendidikan seks pada anak dalam tinjauan agama Islam. Metode yang digunakan ialah kajian literatur. Dari tinjauan agama, Majelis Ulama Indonesia (MUI) mengharamkan perilaku LGBT karena merupakan kejahatan yang dapat menimbulkan penyakit yang berbahaya bagi kesehatan seperti sifilis, hepatitis B, dan HIV/AIDS. Dari tinjauan psikologi, LGBT bisa mengganggu kesejahteraan psikologis seseorang. Oleh karena itu, upaya pencegahan perlu dilakukan sejak dini dimulai dari keluarga yaitu orangtua melalui pendidikan seks yang tepat. Penanaman pendidikan seks terhadap anak harus dilakukan dalam hubungan orangtua dan anak yang hangat dan harmonis agar anak mampu menerimanya dengan baik. Komunikasi orangtua-anak yang didasarkan pada kepercayaan dan keterbukaan menjadi kunci dalam melakukan pendidikan seks yang nyaman bagi anak.

Kata kunci: pendidikan seks, komunikasi, orangtua-anak, LGBT 


\section{Pendahuluan}

Manusia merupakan wakil Tuhan di muka bumi. Manusia diberikan karunia hati, akal, nafsu, dan panca indera untuk melaksanakan amanah yaitu mengelola dan melestarikan kehidupan di muka bumi seseuai petunjuk dari Tuhan. Manusia harus tunduk, patuh, dan taat terhadap aturan yang ditentukan oleh Tuhan sesuai yang ada dalam kitab suci agama masingmasing, khususnya agama Islam di dalam Al Quran. Manusia diberikan kelonggaran untuk menikmati kebutuhan biologisnya yaitu makan, minum, dan menyalurkan hasrat seksualnya. Namun, kelonggaran itu dibatasi oleh aturan-aturan agama. Penyaluran hasrat seksual harus dilakukan terhadap lawan jenis dan dalam ikatan pernikahan (Muhammad Ali al-Sobūnī,1995). Islam melarang adanya hubungan sesama jenis. Hal ini dijelaskan dalam Al Quran surat Al AlA'raf : 80-81 yang artinya

"Dan (kami juga telah mengutus) Luth (kepada kaumnya) mengapa kalian mengerjakan perbuatan fashiyah itu, yang belum pernah dikerjakan oleh seorang pun (di dunia ini) sebelum kalian ?" Sesungguhnya kalian mendatangi lelaki untuk melepaskan nafsu kalian (kepada mereka), bukan kepada wanita, malah kalian ini adalah kaum yang melampaui batas".

Dalam ayat tersebut sudah jelas bahwa perbuatan homoseksual merupakan perbuatan yang tidak sewajarnya dan melampaui batas sehingga di larang. Dan Allah hanya menciptakan manusia dalam jenis kelamin laki-laki atau perempuan, bukan kedua-duanya. Allah menciptakan manusia secera berpasang-pasangan dengan tujuan agar menentramkan hati dan memberikan kenyamanan. Hal ini diterangkan oleh Allah dalam Qs. Al Hujurat ayat 13 dan QS. Al-Zukhruf ayat 12 yang artinya

"Hai manusia, sesungguhnya Kami menciptakan kamu dari seorang laki-laki dan seorang perempuan dan menjadikan kamu berbangsa-bangsa dan bersuku-suku supaya kamu saling mengenal. Sesungguhnya orang yang paling mulia diantara kamu disisi Allah ialah orang yang paling bertakwa diantara kamu. Sesungguhnya Allah Maha Mengetahui lagi Maha Mengenal" (Qs. Al Hujurat: 13).

"Dan Yang menciptakan semua yang berpasang-pasangan dan menjadikan untuk mu kapal dan binatang ternakyang kamu tunggangi" (QS. Al-Zukhruf: 12).

Sejalan dengan pendapat diatas, dari sudut pandang psikologi, psikiatri Fidiansyah (2016) yang menjabat sebagai Wakil Seksi Religi Spiritualitas dan Psikiatri dari Perhimpunan Dokter Spesialis Kejiwaan Indonesia (PDSKJI) menyatakan bahwa LGBT merupakan gangguan jiwa dan bisa menular kepada orang lain. Dalam buku Pedoman Penggolongan Diagnosis 
Gangguan Jiwa (PPDGJ) Homoseksualitas masuk dalam F66X1dan Biseksualitas F66X2. Keduanya dikategorikan gangguan psikologis dan perilaku yang berhubungan dengan perkembangan dan orientasi seksual.

Di Indonesia, jumlah LGBT tergolong cukup banyak. Menurut Santoso (2016) menyatakan bahwa jumlah LGBT di Indonesia mencapai $3 \%$ dari jumlah total penduduk Indonesia sekitar 20 juta jiwa. Artinya, sekitar 7, 3 juta jiwa penduduk Indonesia mengalami penyimpangan orientasi seksual. Ini problem moral yang sangat serius yang sedang di hadapi oleh bangsa Indonesia. Majelis Ulama Indonesia (MUI) sesuai dengan Fatwa MUI Nomor 57 Tahun 2014 tentang Lesbian, Gay, Sodomi, dan Pencabulan telah melarang dan mengharamkan adanya LGBT. Isi dari fatwa tersebut adalah LGBT dilarang dan diharmkan karena merupakan kejahatan yang menimbulkan penyakit berbahaya bagi kesehatan dan sebagai sumber penyakit menular seperti HIV/AIDS (Ermayani, Tri. 2017). Tata aturan perundang-undangan di Indonesia juga melarang adanya LGBT. Hal ini termaktub dalam Undang-Undang Dasar 1945 Pasal 29 ayat 1 dan Pasal 28. LGBT juga bertentangan dengan Undang-Undang No. 20 Tahun 2003 pasal 3 tentang tujuan pendidikan nasional bahwa: "Pendidikan Nasional berfungsi mengembangkan kemampuan dan membentuk watak serta peradaban bangsa yang bermartabat dalam rangka mencerdaskan kehidupan bangsa, bertujuan untuk berkembangnya potensi peserta didik agar menjadi manusia yang beriman dan bertakwa kepada Tuhan Yang Maha Esa, berakhlak mulia, sehat, berilmu, cakap, kreatif, mandiri dan menjadi warga negara yang demokratis serta bertanggung jawab". LGBT hanya akan membuat kecerdasan menurun, tidak memiliki kepribadian yang utuh, dan bertentangan dengan hukum agama dan hukum Negara.

Berdasarkan pendapat-pendapat diatas maka jelas sudah bahwa LGBT merupakan perilaku menyimpang yang dilarang oleh agama dan Negara serta berbahaya secara psikologis. Perilaku LGBT dapat menular ke orang lain bukan melalui virus ataupun bakteri akan tetapi karena pengaruh teman, pergaulan, tontonan, dan sebagainya. LGBT menyebabkan pribadi anak menjadi tidak utuh, melanggar ajaran agama, dan melanggar aturan Negara. Oleh karena itu, salah satu upaya mencegah LGBT dengan memberikan pendidikan seks sejak dini berlandaskan pendekatan agama. Memberikan pendidikan seks untuk anak merupakan amanah yang harus dijalankan oleh orangtua. Sebagai umat Islam, kita mempunyai kewajiban untuk tidak meninggalkan generasi yang lemah. Tujuan memberikan pendidikan seks dalam Islam agar anak mengetahui, memahami, dan mampu menyadari tentang kondisi fisik beserta dengan fungsinya sehingga tidak berperilaku yang melanggar aturan agama (Roqib, 2008). 
Upaya penanaman pendidikan seks pada anak sebagai bentuk pencegahan LGBT harus dalam suasana keluarga yang hangat dan harmonis yang ditunjukkan dengan adanya kedekatan dan keakraban antara orangtua dengan anak agar anak tidak merasa malu dan menganggap "saru/tabu" membicarakan hal-hal yang berkaitan dengan seks. Komunikasi yang dibangun antara orangtua-anak adalah komunikasi yang didasarkan pada kepercayaan dan keterbukaan. Keluarga harus menjadi teladan dalam bersikap terkait dengan seksualitas yang sesuai dengan aturan agama.

\section{Metode Penelitian}

Penelitian ini menggunakan metode kajian literatur atau studi pustaka. Penelitian ini mengkaji tentang LGBT dari tinjauan agama dan psikologi melalui berbagai literatur yang ada. Kajian dilakukan dengan menelusuri, menggali, serta melakukan analisis kritis terhadap kajian yang ditemukan pada dokumen kepustakaan dan hasil penelitian yang relevan.

\section{Hasil Dan Pembahasan}

\section{LGBT Dalam Perspektif Psikologi}

Dahulu dalam DSM (Diagnostic and Statistic Manual of Mental Disorder) I dan II, homoseksualitas dimasukkan sebagai penyimpangan yang termasuk gangguan jiwa. Namun, dalam DSM III, homoseksualitas tidak lagi dianggap sebagai gangguan jiwa setelah mendapatkan kritikan dari American Psychiatric Association (APA). Homoseksualitas dianggap merupakan pilihan orientasi seksual seseorang. Perubahan ini tentu saja berdampak besar terhadap konsep dan legalitas LGBT. Disisi lain, dalam Pedoman Penggolongan Diagnosis Gangguan Jiwa (PPDGJ) Lesbian, Gay, Biseksual, dan Transgender (LGBT) merupakan gangguan jiwa, penyimpangan orientasi seksual, yang bisa menular ke orang lain (Fidiansyah, 2016).

Perbedaan paradigma berpikir tersebut sangat dipengaruhi oleh kultur dan norma dimana pendapat itu muncul. Menurut Malik Badri (1996), pandangan homoseksualitas yang akhirnya dianggap bukan merupakan pemyimpangan yang termasuk gangguan jiwa berasal dari pemikiran psikolog Barat. Dalam DSM, perilaku dianggap menyimpang apabila dalam keadaan maladaptive. Kondisi maladaptive apabila seseorang tidak mampu menyesuaikan diri dengan lingkungan dan dirinya untuk mencapai kebahagiaan. Sedangkan para pelaku homoseksualitas dianggap mampu menyesuaikan diri dan lingkungan sehingga tidak dianggap abnormalitas. Oleh karena itu, perubahan kondisi kultur, norma, dan nilai yang ada di masyarakat akan mempengaruhi perubahan paradigma berpikir mereka tentang LGBT. 
Menurut Tika Bisono (2016), LGBT disebabkan oleh dua faktor yaitu faktor biologis dan faktor sosiologis. Faktor biologis yang dimaksud ialah faktor genetik maupun hormonal yang dibawa oleh individu sejak lahir. Apabila kondisi LGBT disebabkan karena faktor biologis maka bisa disembuhkan dengan terapi hormonal. Meskipun demikian, Tika Bisono (2016) mengatakan bahwa LGBT lebih banyak disebabkan karena faktor sosiologis daripada faktor hormonal. Faktor sosiologis yang dimaksud ialah faktor lingkungan, pergaulan, tontonan, budaya, dan lain-lain. Pendapat berbeda dikemukakan oleh Meyer-Bahlburg (dalam Carlson, 2012) yang menyatakan bahwa LGBT tidak dipengaruhi oleh hormon akan tetapi dipengaruhi oleh struktur otak. Struktur otak homoseksual dengan manusia normal berbeda yang disebabkan karena paparan androgen prenatal.

Dalam tinjauan psikoanalisis, ada lima tahapan perkembangan psikoseksual menurut Freud ((Feist \& Feist, 2014) yaitu fase oral, anal, phallic, latent, genital. Fase yang menentukan individu akan mengalami LGBT atau tidak berada pada fase phallic yang berada di rentang usia 3 sampai 5 tahun. Pada fase ini, individu sangat menyukai alat kelaminnya. Anak laki-laki senang dengan penisnya dan anak perempuan senang dengan vaginanya. Namun, rasa senang anak perempuan tidak sebesar anak laki-laki. Secara umum, anak dekat dengan ibunya. Ia sangat tidak suka jika ayahnya terlalu dekat dengan ibunya. Bagi anak, ayah adalah sosok yang kuat, besar, dan mendominasi. maka ia akan berusaha menjadi figur seperti ayahnya karena telah berhasil menaklukkan ibunya. Perasaan dan persepsi tersebut akan berkembang sampai remaja dan akhirnya menjadikan dia sebagai heteroseksual. Begitu pula dengan anak perempuan. Menurut Freud ((Feist \& Feist, 2014) anak perempuan mengalami kecemburuan terhadap penis (penis envy) sehingga ia ingin mendapatkan itu. Jika masih kecil ia akan mengalihkan kasih saying ayahnya dengan boneka. Jika perasaan itu berkembang sampai remaja maka ia kan menjadi peremuan yang heteroseksual.

\section{LGBT Dalam Perspektif Agama Islam}

Agama Islam berusaha untuk membangun manusia dengan pembangunan yang seimbang dan proporsional yaitu membentuknya dengan bentuk yang sesuai dengan ciptaan dan fitrah yang diciptakan Allah. Islam secara jelas telah mengajarkan kepada umatnya untuk berpegang teguh pada ajaran agama dan melarang untuk mengerjakan perbuatan yang dilarang oleh agama. Termasuk melakukan hubungan sesama jenis. Allah hanya menciptakan manusia laki-laki atau perempuan saja dan bukan kedua-duanya. Hal ini ada dalam Qs. An Najm: 45 dan Qs. Al Hujurat: 13 yang artinya

"Dan Dia (Allah) menciptakan dua pasang dari dua jenis laki-laki dan Perempuan" (Qs. An Najm: 45). 
“Wahai manusia Kami menciptakan kamu yang terdiri dari laki-laki dan perempuan” (Qs. Al Hujurat: 13).

Ayat tersebut dengan tegas menjelaskan bahwa Allah tidak menciptkan jenis kelamin ketiga, abu-abu, ataupun waria. Jika saat ini ada yang menganggap dirinya waria maka itu lebih disebabkan karena faktor lingkungan.

Perilaku homoseksualitas merupakan perilaku yang dilarang karena merupakan perbuatan yang melampaui batas dan merusak fitrah manusia. Perilaku ini pertama kali dilakukan oleh kaum Nabi Luth as. Dalam agama Islam, homoseksual disebut dengan liwath yang artinya hubungan sesama jenis baik berorientasi seksual maupun tidak yang dilandasi dengan rasa cinta dan kasih sayang. Larangan terhadap homoseksualitas tertuang dalam firman Allah Qs. Al A'raf: 81 dan Qs. An Naml: 55 yang artinya:

"Sesungguhnya kamu mendatangi lelaki untuk melepaskan nafsumu kepada mereka, bukan kepada wanita, malah kamu ini adalah kaum yang melampaui batas" (QS. Al A"raf: 81).

"Mengapa kamu mendatangi laki-laki untuk memenuhi nafsumu, bukan mendatangi wanita? Sebenarnya kamu adalah kaum yang tidak mengetahui akibat perbuatanmu" (QS. An Naml: 55).

Ayat diatas dengan tegas menyatakan bahwa kaum homoseksual merupakan kaum yang melampaui batas. Allah telah menciptakan manusia laki-laki dan perempuan. Mereka diciptakan secara berpasang-pasangan agar mendapatkan ketentraman. Allah sudah mengatur sedemikian rupa tentang orientasi seksual manusia jika mereka melanggar maka akan ada akibatnya. Akibat dari perbuatan LGBT ialah timbulnya berbagai macam penyakit seperti HIV, Sifilis, AIDS, dan sebagainya, stress, penggunaan narkoba, pecandu alkohol, perokok, serta memutus rantai kehidupan manusia karena pelaku homoseksual tidak bisa meneruskan keturunan yang disebabkan mereka tidak bisa melakukan reproduksi.

\section{Pendidikan Seks Berbasis Relasi Orangtua-Anak}

\section{Pendidikan Seks Dalam Islam}

LGBT semakin marak akhir-akhir ini sehingga sebagai orangtua harus melakukan upaya pencegahan dengan memberikan pendidikan seks pada anak. Masalah seksual membutuhkan pengarahan, bukan pembentukan atau pembangunan sebab hal ini sudah tertanam dalam diri manusia. Oleh karena itu, perlunya mengarahkan kecenderungan seksual merupakan aktivitas pendidikan. Dalam Islam, memberikan pendidikan dan pengasuhan yang tepat merupakan 


\section{WACANA}

amanah yang harus dilakukan sebagai orangtua termasuk memberikan pendidikan seks. Kewajiban orangtua untuk memberikan pendidikan terhadapa anak terdapat dalam Qs. At Tahrim: 6 yang artinya

"Wahai orang-orang yang beriman, peliharalah dirimu dan keluargamu dari api neraka".

Ayat diatas menjelaskan bahwa ayah dan ibu mempunyai tugas untuk menjaga keluaarganya agar tidak masuk ke neraka. Pendidikan seks pada anak merupakan upaya penting yang dilakukan orangtua agar anak tidak terjerumus kepada perilaku LGBT yaitu perilaku yang dilarang oleh agama sehingga mereka tidak terjerumus ke dalam neraka. Keluarga harus mulai membiasakan menanamkan pendidikan seks kepada anak sejak dini dan menganggap bahwa membicarakan persoalan seks bukan merupakan hal yang tabu. Yang paling penting ialah membiacarakan seksualitas harus dilakukan dalam kondisi yang nyaman, anak tidak merasa terbebani, dan materi seksualitas disesuaikan dengan usia anak.

Pendidikan seks ialah sebuah upaya memberikan informasi tentang kondisi fisik individu dan fungsinya yang terkait dengan jenis kelamin laki-laki dan perempuan serta mengajarkan tentang nilai-nilai dan aturan yang harus ditaati agar sesorang tidak melakukan perbuatan yang melanggar aturan agama termasuk melakukan perilaku homoseksual (Roqib, 2018).

Menurut Roqib (2018) tujuan memberikan pendidikan seks pada anak ialah agar anak bisa memahami kondisi fisiknya. Bahwa antara laki-laki dan perempuan berbeda secara fisik. Perempuan memunyai alat kelamin yang berbeda dengan laki-laki, mempunyai organ reproduksi yang dapat dibuahi dan dapat membuatnya hamil. Selain itu, untuk menumbuhkan rasa cinta dan sayang dengan lawan jenis yang akhirnya nanti jika mereka sudah dewasa akan mampu menyalurkan hasrat seksualnya dengan pernikahan untuk menuju keluarga yang sakinah, mawadah, warahmah. Mereka akhirnya memahami bahwa pernikahan adalah jalan halal yang harus mereka tempuh untuk menyalurkan hasrat seksualnya.

Kecenderungan seksual dalam diri anak agar mengalir dengan tenang tanpa gangguan eksternal yang dapat menyebabkannya melenceng dari perilaku yang lurus, Islam menjaga naka-anak dengan memberinya perintah dan larangan. Kaidah dan dasar-dasar yang diajarkan oleh Rasulullah dalam mengarahkan kecenderungan seksual anak agar diikuti oleh kedua orangtua agar anaknya terhindar dari penyimpangan seksual, ftrahnya bersih dan suci (Suwaid, 2014) ialah:

1) Melatih anak meminta izin ketika masuk rumah atau kamar orangtua. Ada tiga waktu yang diatur dalam Al Quran anak harus meminta izin kepada orangtuanya untuk masuk kamar yaitu 
sebelum shalat subuh, waktu tidur siang, dan setelah salat Isya supaya pandangan mereka tidak jatuh pada aurat keluarganya. Beberapa keluarga mungkin menganggap remeh adab tersebut karena mereka menganggap anak-anak masih kecil. Padahal menurut para psikolog (Suwaid, 2014) bahwa pemandangan yang dilihat anak-anak kecil bisa menyebabkan anak mengalami penyakit kejiwaan dan fanatisme yang sulit disembuhkan.

2) Membiasakan anak menundukkan pandangan dan menutup aurat. Pandangan adalah jendela anak untuk melihat alam luar. Apa yang dilihat oleh kedua mata anak akan tertanam diingatannya. Apabila seorang anak terbiasa menundukkan pandangan dari segala aurat maka itu akan mewariskan manisnya iman di hati anak sehingga naluri seksualnya tidak matang sebelum waktunya yang bisa menyebabkan kerusakan bagi jasmani dan ruhaninya. Perintah Allah agar anak dibiasakan menutup aurat bersamaan dengan perintah untuk mengerjakan salat. Anak perempuan dan anak laki-laki wajib menutup aurat. Anak perempuan wajib memakai hijab. Dengan demikian anak akan tumbuh dengan kesalehan, teratur jiwanya, lurus akhlaknya, dan kuat imannya.

3) Memisahkan tempat tidur anak. Ini merupakan upaya untuk mengarahkan kecenderungan seksual anak dan tidak menumbuhkan naluri seksualnya secara negatif. Pemisahan tersebut dilakukan pada saat anak-anak berusia 10 tahun yaitu pada saat naluri seksual sedang mulai tumbuh. Memisahkan tempat tidur anak yang dimaksud di sini ialah memisahkan dua anak untuk tidak tidur dalam satu selimut dan dalam satu tempat tidur. Hal itu dilakukan karena dikhawatirkan akan menimbulkan syahwat. Tidur dalam satu selimut akan dapat menyebabkan naluri seksual anak tumbuh dengan lebih cepat dan dapat disalurkan dengan cara yang salah.

4) Melatih anak dalam posisi tidur ke kanan. Tidur miring ke kanan akan menjauhkan anak dari bentuk penyelewengan seksual waktu tidur. Nabi Muhammad mengatakan bahwa tidur terlentang adalah tidurnya seta. Apabila anak tidur tengkurap, akan menyebabkan sering terjadinya pergesekan pada organ reproduksinya sehingga dapat membangunkan syahwatnya. Apabila kedua orangtua melihat anak mereka tidur dalam dua keadaan tersebut hendaknya segera menubah posisi tidurnya. Kedua orang tua juga menasehati anak hendaknya tidur miring ke kanan dan jangan tidur tengkurap.

5) Menjauhkan anak dari berduaan bersama lawan jenis. Berduaan dengan lawan jenis bisa menimbulkan perilaku yang menyimpang dari aturan agama. Berduaan dengan lawan jenis bisa menimbulkan munculnya syahwat.

6) Mengajarkan kewajiban mandi janabah ketika anak mendekati baligh. Ketika sudah memperikrakan dekatnya usia baligh sang anak, pada saat itulah mereka berdua wajib 
mengajarkan mandi junub untuk menggugurkan dosa besar kepada anak-anaknya. Orangtua juga memberitahu tentang alasan menagapa mandi junub. Inti dari pendidikan tersebut ialah mereka akan memasuki usia dengan beban tanggung jawab yang berbeda dari usia sebelumnya. Semua perilaku yang dilakukan akan dimintai pertanggungjawaban oleh Allah.

7) Menjelaskan perbedaan jenis kelamin dan bahaya zina ketika anak mendekati baligh. Islam mengajarkan supaya anak mempelajari surat An Nur yang didalamnya terkandung ajaran tentang penbentukan akhlak, pengarahan kecenderungan seksual bagi anak, dan peringatan dari perbuatan zina. Hal ini perlu dilakukan supaya anak mempunyai iman yang kuat apabila mereka nanti tinggal di negara yang semuanya serba beas dan jauh dari nilai-nilai islami.

8) Menganjurkan pernikahan dini pada anak. Pernikahan dini menjadi sebuah hal yang patut dan wajib kita pertimbangkan ketika anak sudah memasuki usia baligh dan mampu melakukan hubungan seksual di zaman sekarang. Terlebih apabila anak sudah mampu mengamankan kehidupan finasial dalam keluarga, baik untuk membantu kedua orang tua maupun untuk membantu dirinya sendiri. Penyakit kejiwaan dan sosial dalam masyarakat serta berbagai peristiwa criminal yang terjadi tidak lain merupakan akibat dari memperlambat pernikahan.

Menurut Reiss dan Halstead (2006) pendidikan seks pada anak bertujuan untuk 1) Memberikan pengetahuan kepada anak tentang topik-topik seks misalnya mengenal jenis kelamin, funsi laat kelamin, dan sebagainya, 2) Mencegah anak-anak dari tindak kekerasan, 3) Mengurangi rasa bersalah, rasa malu, dan kecemasan akibat tindakan seksual, 4) Mendorong hubungan yang baik, 5) Membantu anak muda yang bertanya tentang peran laki-laki dan perempuan di masyarakat.

Untuk menanamkan pendidikan seks anak usia dini dibutuhkan strategi yang tepat. Menurut Kriswanto (dalam Roqib, 2008) menyatakan bahwa ada beberapa strategi yang perlu dilakukan dalam penanaman pendidikan seks terhadap anak agar berjalan dengan efektif yaitu:

1. Membantu anak agar ia merasa nyaman dengan tubuhnya.

2. Memberikan sentuhan dan pelukan kepada anak agar mereka merasakan kasih sayang dari orangtuanya secara tulus.

3. Membantu anak memahami perbedaan perilaku yang boleh dan yang tidak boleh dilakukan di depan umum seperti anak selesai mandi harus mengenakan baju kembali di dalam kamar mandi atau di dalam kamar. Anak diberi tahu tentang hal-hal pribadi, tidak boleh disentuh, dan dilihat orang lain.

4. Mengajar anak untuk mengetahui perbedaan anatomi tubuh laki-laki dan perempuan. 
5. Memberikan penjelasan tentang proses perkembangan tubuh seperti hamil dan melahirkan dalam kalimat yang sederhana, bagaimana bayi bisa dalam kandungan ibu sesuai tingkat kognitif anak. Tidak diperkenankan berbohong kepada anak seperti "adik datang dari langit atau dibawa burung". Penjelasan disesuaikan dengan keingintahuan atau pertanyaan anak misalnya dengan contoh yang terjadi pada binatang.

6. Memberikan pemahaman tentang fungsi anggota tubuh secara wajar yang mampu menghindarkan diri dari perasaan malu dan bersalah atas bentuk serta fungsi tubuhnya sendiri.

7. Mengajarkan anak untuk mengetahui nama-nama yang benar pada setiap bagian tubuh dan fungsinya. Vagina adalah nama alat kelamin perempuan dan penis adalah alat kelamin pria, daripada mengatakan dompet atau burung.

8. Membantu anak memahami konsep pribadi dan mengajarkan kepada mereka kalau pembicaraan seks adalah pribadi.

9. Memberi dukungan dan suasana kondusif agar anak mau berkonsultasi kepada orangtua untuk setiap pertanyaan tentang seks.

10. Perlu ditambahkan, teknik pendidikan seks dengan memberikan pemahaman kepada anak tentang susunan keluarga (nasab) sehingga memahami struktur sosial dan ajaran agama yang terkait dengan pergaulan laki-laki dan perempuan.

11. Membiasakan dengan pakaian yang sesuai dengan jenis kelaminnya dalam kehidupan sehari-hari dan juga saat melaksanakan salat akan mempermudah anak memahami dan menghormati anggota tubuhnya.

\section{Komunikasi Pendidikan Seks Dalam Keluarga}

Komunikasi mempunyai peran penting dalam pengasuhan terhadap anak. Pola komunikasi menentukan pola pengasuhan terhadap anak. Pengertian komunikasi dalam Kamus Besar Bahasa Indonesia ialah proses penyampaian dan penerima lambang-lambang yang mengandung arti, baik yang berujud informasi-informasi, pemikiran-pemikiran dan pengetahuan (Depdikbud, 1990).

Dalam islam, komunikasi juga dijelaskan di dalam Qs. Ar Rahman ayat 1-4 dan Qs. Al Baqarah ayat 31-33 yang berbunyi

"Tuhan yang Maha Pemurah, yang telah mengajarkan Alquran. Dia menciptakan manusia, yang mengajarinya pandai berbicara". (Qs. Ar Rahman: 1-4)

"Dan Dia mengajarkan kepada Adam nama-nama (benda-benda) seluruhnya, kemudian mengemukakannya kepada para Malaikat lalu berfirman: 'Sebutkanlah kepada-Ku nama 
benda-benda itu jika kamu mamang benar orang-orang yang benar!' Mereka menjawab: 'Maha Suci Engkau, tidak ada yang kami ketahui selain dari apa yang telah Engkau ajarkan kepada kami; sesungguhnya Engkaulah Yang Maha Mengetahui lagi Maha Bijaksana.' 'Allah berfirman: 'Hai Adam, beritahukanlah kepada mereka nama-nama benda ini.' Maka setelah diberitahukannya kepada mereka nama-nama benda itu, Allah berfirman: 'Bukankah sudah Ku katakan kepadamu bahwa sesungguhnya Aku mengetahui rahasia langit dan bumi dan mengetahui apa yang kamu lahirkan dan apa yang kamu sembunyikan?". (Qs. Al Baqarah: 31-33)

Dari kedua ayat tersebut diatas menjelaskan bahwa Allah telah mengajarkan kepada manusia tentang berbahasa yaitu bahwa benda-benda baik yang ada di langit maupun di bumi semuanya itu ada namanya. Bahasa merupakan symbol yang digunakan dalam berkomunikasi.

Komunikasi orangtua dan anak ditinjau dari teori dialog yang dikemukakan oleh Martin Buber (Littlejohn dan Foss, 2009) menghasilkan makna yang diperoleh dari hasil pertukaran informasi antara orangtua dan anak. Dalam konteks pendidikan seks pada anak, makna yang diperoleh ialah pemahaman anak mengenai topik yang berkaitan dengan seksualitas. Menurut Buber yang menjadi titik fokus pada teori dialog ini adalah I-Thou dan I-It (Littlejohn dan Foss 2009). I-Thou ialah kemampuan seseorang untuk berkomunikasi secara jujur, terus terang, spontan, dan bertanggung jawab. Pada I-Thou komunikator tidak memaksa komunikan untuk menerima pandangannya namun terjadi proses dialog apabila terjadi perbedaan pendapat maupun pandangan sehingga mampu menemukan kesimpulan yang disepakati bersama. I-It ialah kemampuan komunikator untuk mempengaruhi komunikan agar tujuannya tercapai. Dua hal tersebut bisa menjadi dasar dalam melakukan komunikasi pendidikan seks terhadap anak termasuk anak usia dini.

Komunikasi orangtua-anak perlu didasari oleh dua hal yaitu kepercayaan dan keterbukaan (Mulyana, 2000). Dua hal mendasar tersebut juga diperlukan oleh orangtua dalam berkomunikasi menanamkan pendidikan seks terhadap anak. Orangtua perlu membangun kepercayaan anak terhadap orangtua misalnya dengan membuat situasi yang nyaman saat berkomunikasi, memberikan sentuhan maupun pelukan yang menunjukkan kasih sayang kepada anak, dan berbicara dengan suara yang jelas namun lembut. Dengan munculnya kepercayaan anak terhadap orangtua maka munculah keter bukaan anak. Anak tidak merasa malu untuk berbicara tentang seksualitas dan mampu serta mau mendengarkan pembicaraan orangtua tentang topik tersebut. Orangtua harus mampu menjadi sahabat yang menyenangkan bagi anak. 


\section{Kesimpulan}

Psikologi memandang LGBT merupakan gangguan jiwa dan bisa menular kepada orang lain. Hal ini tertuang dalam Pedoman Penggolongan Diagnosis Gangguan Jiwa (PPDGJ) Homoseksualitas masuk dalam F66X1dan Biseksualitas F66X2. Dari tinjauan agama Islam perilaku homoseksualitas merupakan perilaku yang dilarang karena merupakan perbuatan yang melampaui batas dan merusak fitrah manusia.

Salah satu upaya melakukan pencegahan perilaku homoseksual/LGBT adalah dengan memberikan pengetahuan kepada anak tentang pendidikan seks. Pendidikan seks dilakukan melalui komunikasi yang hangat, empatik, dan bersifat dialogis antara orangtua dengan anak. komunikasi tersebut akan tercipta apabila ada kepercayaan dan keterbukaan diantara keduanya. Pola komunikasi yang terbangun akan mempengaruhi pola asuh orangtua terhadap anak. Materi-materi pendidikan seks untuk anak ialah 1) Melatih anak meminta izin ketika masuk rumah atau kamar orangtua, 2) Membiasakan anak menundukkan pandangan dan menutup aurat, 3) Memisahkan tempat tidur anak, 4) Melatih anak dalam posisi tidur ke kanan, 5) Menjauhkan anak dari berduaan bersama lawan jenis, 6) Mengajarkan kewajiban mandi janabah ketika anak mendekati baligh, 7) Menjelaskan perbedaan jenis kelamin dan bahaya zina ketika anak mendekati baligh, dan 8) Menganjurkan pernikahan dini pada anak. 
WACANA

\section{Daftar Pustaka}

Ali al-Sobūnī, Muhammad.Rawāiu. 1995. Al-Bayān Tasfīr Āyātul Ahkām Min Al-Qurān, Juz II, Makkah: Dirosah Islamiyah

Badri, Malik. 1996. The Dilemma of Muslim Psychologyst, Terj; Siti Zainab Luxfiati, Dilema Psikolog Muslim. Jakarta: Pustaka Firdaus

Carlson, N. 2012. Fisiologi Perilaku. Jakarta: Erlangga

Deddy Mulyana. 2000. Ilmu Komunikasi Suatu Pengantar . Bandung: Remaja Rosdakarya

Departemen Pendidikan dan Kebudayaan. 1990. Kamus Besar Bahasa Indonesia. Jakarta: Balai Pustaka.

Feist, J., \& Feist, G. 2014. Teori Kepribadian. Jakarta: Salemba Humanika.

Firdiansyah. 2016. "LGBT Marak, Apa Sikap Kita?" dalam diskusi Indonesian Lawyer's Club (ILC), di TV.ONE, Selasa16 Februari.

Littlejohn, Stephen W dan Karen A. Foss. (2009). Teori Komunikasi: Theories of Human Communication edisi 9. Jakarta: Salemba Humanika

Reiss, Michael, dkk. 2006. Pendidikan Seks Bagi Remaja: dari Prinsip ke Praktik. Yogyakarta: Alenia Press.

Roqib, Moh. 2018. Pendidikan Seks Pada Anak Usia Dini. Jurnal INSANIA|Vol. 13|No. 2|Mei-Ags $2008 \mid 271-28$

Santoso, M. B. 2016. LGBT dalam Perspektif Hak Asasi Manusia. Social Work Journal , 6 (2), 154272

Suwaid, Muhammad Nur Abduh Hfizh. 2010. Prophetic Parenting: Cara Nabi Saw Mendidik Anak. Yogyakarta: Pro-U media 